\title{
THE FAILINGS OF LEGAL CENTRALISM FOR HELPING STOCK MARKETS IN TRANSITION
}

Edward STRINGHAM, Department of Economics, San Jose State University, Peter BOETTKE, Department of Economics, George Mason University, Fairfax

\section{Introduction}

After the collapse of communism in 1989 optimism about adopting capitalist institutions in Eastern Europe was widespread, and, in the Czech Republic especially, Václav Klaus was heralded as ushering in a radical economic reform (see Palmer, 1997). Yet within a few years it became evident that the newly created stock markets were far from perfect. A December 23, 1996 article in Fortune Magazine entitled "The Pirates of Prague" described an important problem: firm managers and investment funds were often acting against the interests of minority shareholders and tunneling resources into their own coffers (see Wallace, 1996; Johnson et al, 2000) ${ }^{1)}$ These problems led many to question the existing legal arrangements and to ponder the necessary prerequisites for capital market development.

Most commentators including Black (2001), Coffee (1999), Frye (2000), Glaeser et al (2001), Mlčoch (2000), Pistor (2001) and Stiglitz (1999) argue the experience of Eastern Europe poses a serious challenge to those economists who maintain that government oversight of financial markets is unnecessary. While writers such as Benston (1998), Manne (1969), and Stigler (1964) argued that forward looking economic agents would contract for arrangements to maximize the value of their equities, Glaeser et al (2001) counter that this group of theories "crucially relies, among other assumptions, on the possibility of effective judicial enforcement of complicated contracts." ${ }^{2)}$ In most Eastern European countries the condition of a well functioning judiciary clearly is not met (see Santomero, 1998) so Glaeser et al argue that some other government agency need to step in to fill the void. After all

*) We thank Vladimir Benáček, Bryan Caplan, Christopher Coyne, Tomas Jezek, Radovan Kacin, Peter Leeson, Lubomír MIčoch, Tomas Sedlacek, Josef Šíma, Dan Š•astný, Dusan Triska, Tereza Urbanova, and participants at The American Institute on Political and Economic Systems at Charles University for helpful comments and discussions. Financial assistance from the Weaver Family, Kaplan Fund and the Fund for Amtrican Studies is yratefutty acknowledged. The usual disclaimer applies.

1) Glaeser et al (2001) list the following problems with Czech markets: Transactions could take place off the exchange at below market price, nor was there price uniformity on the exchange; No requirement of new ownership disclosure; No mandatory bid to buy out remaining shareholders; Investment Privatization Funds had no restrictions against pursuing such transactions and had no legal responsibility to their investors; New shareholders and company could make deals without making them public until the annual report was released; Minority shareholders had no legal recourse.

2) Although Coase $(1975$, p. 61$)$ is generally critical of regulations with conclusions such as: "The main lesson to be drawn from these studies [of government regulation of industry] is clear: they all tend to suggest that the regulation is either ineffective or that when it has a noticeable impact, on balance the effect is bad, so that consumers obtain a worse product or a higher-priced product or both as a result of regulation," Glaeser et al argue that Coase is only critical of regulations when the judicial system is effective. 
some government agency must enforce the rules (see Buchanan, 1975; Brennan, Buchanan, 1985).

Despite the very big problem of fraud in Czech stock markets, political economy points out that a government may lack the ability to eliminate a problem. Williamson (1983, p. 537) criticizes what he calls legal centralism writing, "There is a growing awareness that the (comparative) limitations of the courts are more severe than the legal centralism tradition admits." The law, whether enforced by courts or regulators, is often highly imperfect, so one cannot assume that additional rules will eliminate any given problem. ${ }^{3)}$ In the real world drawing up contract that will eliminate opportunism is often impossible or at least at extremely costly, so organizing one's economic activity around the law is often not an option. Recent work by Benson (1990), Bernstein (1992), Clay (1997), Ellickson (1991), Johnsen (1986), Leeson (forthcoming), and Stringham (2003) documents how markets function much differently from how the law would actually prescribe. Government rule enforcers often lack the incentive or the ability to solve problems such as fraud, so market participants are left on their own.

Nevertheless, the legal centralist approach is quite popular in the realm of public policy where the hope has been that stricter rules will make stock markets more attractive. Most commentators on the Czech Republic believed that the agency problems were due to insufficient laws and that the problems could be solved by additional governmental rules. Yet wishing something so does not make it so, and in the Czech Republic especially the additional regulations have not delivered. Despite adding an independent Securities Exchange Commission and numerous additional regulations since 1998, the Czech government has hardly created confidence in the Czech stock market, instead they created numerous regulations that burden the market and do little to reduce the existing problems. We believe that the experience of the Czech stock markets shows the failings of legal centralism from a positive and normative perspective. By studying the problems of legal centralism in this context we can learn which policies are less or more likely to be successful in the future. Our paper is organized as follows: Section 2 discusses why the legal centralist approach is unlikely to produce good corporate governance, Section 3 provides examples of the failings of the legal centralist approach in the Czech experience, and Section 4 concludes.

\section{Is good corporategovernancelikely to comefrom the state?}

Whenever exchange moves beyond simple face to face transactions the potential for post contractual opportunism exists. The stock market is a prime example, where managers promise to pay profits in the future but they may have no intention of delivering. As Shleifer and Vishny (1997, p. 740-741) explain:

„The manager needs the financiers' funds, since he either does not have enough capital to invest or he wants to cash out the holdings. But how can the financier be sure that, once they sink their funds, they get anything but a worthless piece of paper back from the manager?"

If managers are unable commit to follow through on their bargain, investors will withhold funds and the capital market will dry up. The dilemma is figuring how to stop managers from mishandling the shareholders capital. The most commonly invoked solution is the legal centralist view: simply have the law stipulate that managers maximize the value to the shareholders. Under this lega-

3) Robert Ellickson (1987) describes legal centralists as people who believe that "the legal system-the rules and might of Leviathan-is the wellspring of social order." 
listic approach, in the case of non-compliance shareholders, prosecutors, or regulators simply would file suit and the courts or regulators would rectify the problem. Whether the law is enforced by courts or regulators, the government enforcement apparatus plays a crucial role (see Glaeser et al., 2001; Olson, 1996).

Although the theoretical solution of government contract enforcement is neat and tidy, real world business relationships are often more complicated than the textbook model. Hart and Moore explain (1988, p. 755):

„When drawing up a contract, it is often impracticable for the parties to specify all the relevant contingencies. In particular, they may be unable to describe the states of the world in enough detail that an outsider (the courts) could later verify which state had occurred, and so the contract will be incomplete."

Because contracts that describe all states of the world are simply not an option, the law cannot function as mechanistically as many legal centralists might hope. ${ }^{4)}$ Exactly how the law can ensure that managers act in the interest of their principles is unclear. Consider the simplest prescriptive law that gives managers "the legal duty to maximize profits," which Greenfield and Kostant (2003, p. $1005)$ argue is "essential." Although it might be desirable if such a law could be enforced, uncertainty of economic activity makes such a rule all but unusable. For example, when a company fails to make profits an external observer might not know if the poor performance is due to managerial delinquency, unforeseen business conditions, or a conscious decision to forego profits in favor of more investments. ${ }^{5}$ The legalistic approach that mandates that managers maximize profits would require the courts or regulators to review earnings, judge corporate performance, and decide whether a manager is doing a good job.

Giving government officials the discretion of deciding whether managers are acting in the interest of their principles, introduces many potential problems. Without knowing the specifics of each industry and the specific plan of each company, even a well-intentioned government will have little guidance in deciding each case for many of the reasons given in the socialist calculation debate by Mises (1990) and Hayek (1948). Stiglitz rightly points out that if judges and regulators are so well suited to guide the course of industry, we might as well not have privatization (1999, p. 12):

„It will be said, perhaps the answer lies with better regulations and well-designed incentive contracts for the controlling fund managers. But let us now step back and take stock. If a government had such incredible monitoring and enforcement powers to overcome such disincentives, why not apply those powers directly in corporatized state-owned enterprises and then privatize later in a better thought-out way?"

Whether or not one believes that the problems of central planning can be overcome, one must recognize that having courts or regulators judge winners

4) One example of this line of thinking is James Buchanan (1975) who writes, "Ideally or conceptually, enforcement might be mechanically programmed in advance of law violation. The participants agree on a structure of individual rights or claims that is to be enforced, and violation requires only the findings of fact and the automatic administration of sanctions." Buchanan does add many qualifiers to the above view, but he never really explains why the law enforcement agency will serve the public interest as he would like.

5) No matter the profit level, an outside observe can never say a firm maximized the profits as much as was possible because in hindsight one can observe better possible courses of action, for example betting on the winning lottery number. Unless a firm transferred all of its resources in areas that received the highest possible rates of return, the firm is not making as much profits as was potentially possible. In the market, investors make decisions based on their ex ante willingness to bear risk, but how courts could determine whether a firm's decisions are "optimal" is unclear. 
and losers pushes one exceedingly close to a planned economy. In reality judges are not omniscient (see Stringham, 2001) and will face difficulties making decisions about whether a manager is acting in the interest of his investors. ${ }^{6}$ )

An alternative legalistic approach might create proscriptive laws such as "don't steal the company's value from investors" (see Black, 2001, p. 842) but again whether this legalistic approach can eliminate the problem is unclear. A judge might be able to observe if the manager is transferring funds from the company's account to his personal account, but beyond that where the line of illegal activity is drawn is entirely unclear. A manager might fly coach or he might purchase an expensive corporate jet; a manager might have a Spartan office or the most expensive furniture. Unless the government knows the ideal mode of transport or the ideal set of furniture, then vague proscriptive laws are of little use. And even if the government could ascertain what type of office furniture is excessive, the law would have a difficult time preventing the managers from wasting money because the law would have to cover not just office furniture but everything that enters into a managers utility function. For example, if the law mandated "No excessive furniture" this would not prevent the manager from wasting resources on unneeded jets, lavish carpets, or expensive corporate outings. Unless a law can plug all possible loopholes it is unclear whether it can eliminate the misuse of funds. Imagine trying to keep the water in a flooding bathtub by holding up a bunch of tiny plastic bags. The bags might prevent water from flowing in any particular area but they will not prevent the water from getting around them. This is why, despite all the existing rules and regulations, the law does not prevent management at companies such as Enron from driving their companies into bankruptcy. Most existing laws contain specific obligations such as requiring companies to produce annual reports or have shareholder meetings in certain ways, but such laws can never guarantee that managers are working to maximize profits.

Despite the fact that the law cannot guarantee that shareholders will be well served, the market has mechanisms to deal with this seemingly intractable problem. Rather than relying on courts or regulators to punish managers who do a bad job, the market automatically provides positive reinforcement for those who do a good job. The market for managerial labour and the market for corporate control use no legal force but they create strong incentives to reward those who do well (see Manne, 1969; Klein, 1996; Easterbrook, 1997). Yes, managers need to be monitored, but rather than have the monitoring done by the law, the monitoring takes place almost invisibly by countless entrepreneurs.

Ludwig von Mises described how investor-entrepreneurs who direct resources into different firms call the shots for industry. When investors decide whether a firm deserves their capital, they decide whether an endeavor and its management is worthwhile. The investor-entrepreneurs actually own the company but they cannot make every minute decision for a company so they must delegate responsibilities to employees, one of the most important of whom is the manager who in the words of Mises (1998, p. 301) is „a junior partner of the entrepre-

6) This knowledge problem would not be eliminated if the law contained more specific prescriptive measures. For example, the law would contain more specifics such as "choose the least cost input combinations" and "produce up until the point where marginal benefits equal marginal costs" but unless the government could observe the relevant isoquants and cost curves such a law would also be of little use. Buchanan (1969) gives us reason to question whether government would be able to estimate a firm's cost curve and we would be surprised how many judges even know what "least cost input combination" even means. For such a legalistic approach to function the law enforcers would have to have wisdom about the economy that it just does not have (see Stringham, 2001). 
neur, as it were, no matter what the contractual and financial terms of his employment are." The investors must decide if the manager is the right person for the job, and, like all employers, the investors must monitor their employees. There is a large literature on how employers must use incentives, not laws, to motivate their employees (see Sappington, 1991). When investors hire someone to run a business they are faced with the unavoidable choice of deciding the best person, and even though millions of people meet the legal requirements, not everyone will do a good job. Most potential managers would probably be unsuccessful at running a particular business, not because of willful intent to defraud but because they lack qualifications or business knowledge. In the end, the legal system gives little practical direction whatsoever. ${ }^{7)}$

The owners must decide whom to hire, not based on information provided by government, but based on personal judgment. Owners who are better at selecting good managers will be have higher returns than those who pick poorly, ${ }^{8}$ and whether we like it or not the government has little ability to rescue people from bad decisions. Despite the relative lack of guidance given by the law the market automatically creates incentives for people to do a good job. Mises writes (1998, p. 306):

„In profit-seeking business the discretion of managers and sub-managers is restricted by consideration of profit and loss. The profit motive is the only directive needed to make them subservient to the wishes of the consumers. There is no need to restrict their discretion by minute instructions and details. If they are efficient, such meddling with details would be superfluous, if not pernicious in tying their hands. If they are inefficient, it would not render their activities more successful. It would only provide them with a lame excuse that the failure was caused by inappropriate rules."

Formal law and strict bureaucratic rules in a corporation, by themselves, are unable to ensure that managers act in the interest of principal shareholders. Principle agent problems are real but market institutions have evolved to detect and correct errors that result from these problems (see Padilla, 2002). ${ }^{\text {) }}$ The profit system, the market for corporate control, and the market for managerial labour makes sure that in the long run, good managers will keep their jobs and the bad managers will be put out of business. Government regulation, on the other

7) Just because an investment is legal does not mean the investment is financially sound. For example, in 1992 the American Stock Exchange created the Emerging Company Marketplace designed for "small, high growth companies," and even though investors had the same legal protections as for all other US stocks, so many companies failed that Amex had to end the program because investors lost trust in the companies listed therein (see Coffee, 1999, p. 22).

8) Likewise the managers who do a good job are rewarded through the market for managerial labour. The issue is whether someone can convey that they can be trusted to do a good job in the future (see Diamond, 1989).

9) In order for the original owner to maximize the value of what he offers, he must provide assurances for potential investors. This includes a number of measures such as selecting the best possible arrangements for the secondary market (see Chemmanur, Fulghieri, 2002). To the extent that trading rules can eliminate problems, investors will be willing to pay a premium for a covered stock so it is in the incentive of all parties to select them. Historically the institution that filled this role for the secondary market was private stock exchanges, which can create listing requirements, disclosure requirements, and trading guidelines. (see Banner, 1998; Mahoney, 1997; Stringham, 2002) A system of private regulation has certain advantages over government regulation because under a system of free enterprise stock exchanges must compete to attract capital and will have an incentive to offer attractive trading environments; this contrasts with members of the bureaucracy who do not always have the best business sense or incentives that are aligned with the investment community. McLindon (1996, p. 70) addresses the situation transition economies face „Given the limited administrative talent of government... it is advisable to stress self-regulation by private sector groups. Financial systems have languished for decades under government domination, and the investing public will be wary if government domination continues in a newly emerging capital market. In a liberalized financial system, finance must be depoliticized as much as possible." 
hand, does little to stop bad business and it often imposes a burden on managers and investors alike (see Stigler, 1975).

\section{Why legal centralism has not served Czech markets}

Legal centralists envision the law as a deus ex machina that comes down and solves all problems. In reality the law never works as mechanistically as its supporters envision and the experience of the Czech stock market is a perfect example. After privatization, the Czechs believed that good corporate governance could be attained by telling managers of government enterprises that they have to maximize the value of their company for their newfound shareholders. When it became evident that these government appointees were doing otherwise, the Czech government believed that the solution was to enact additional rules. In practice, it turned out that the legal and regulatory rules did little to help the shareholders, and they ended placing many restrictions on competition. The laws have been tremendously costly yet as we would predict they have done little to restore confidence in the Czech stock market. Let us consider some of the failings of the legalistic approach in the Czech Republic. One of the most basic problems with legal centralism is that the legal systems do not operate according to the textbook model of the law and in the Czech Republic this clearly is the case. Legal centralists usually assume that if someone is breaking a law or contract, one simply goes to court and the issue is resolved, yet courts, especially those in former communist countries, are often ill equipped to enforce even the simplest of contracts. Zemplinerova (2000) explains the situation:

"The Czech legal environment is still in its infancy: it is over-regulated and often bureaucratic. Laws are often difficult to interpret and burdened with inconsistencies and loopholes...In addition, the state judiciary infrastructure is overburdened to the point of paralysis, lacking both the human and financial capital necessary to enforce either statutes or contracts."

In one interview, an American who worked in Prague during the 1990s told us, "I personally am owed $\$ 20,000$ for a 1994 transaction that is still backed up in Czech courts for a case that is open and shut in Czech law." Describing the legal system he said, "It's absurd" (see Personal Interview, San Jose, May 7, 2005) As of 2003, Czech regional courts had 67,000 unsettled cases, with over a third of them being more than five years old (see Bouc, 2004, p. 8). Czech judges lack experience with capital markets and are ill prepared to deal with complicated financial contracts, so economists such as Glaeser et al (2001) suggest that regulators step into fill that void. Judges in former communist economies have little experience with capital markets so they understandably are not completely knowledgeable, but will regulators coming out of the same context fare any better? In our research the evidence seems to indicate that Czech regulators are just as incompetent (see Stringham, Boettke, 2005). Those who advocate the regulations do not seem to recognize the potential for gover- 
nment failure due to knowledge problems or Public Choice concerns. ${ }^{10)}$ The list of questionable regulations is long but let us highlight a few examples.

Throughout its short history the Czech capital market has been accompanied by numerous regulations, ${ }^{11)}$ the amount increasing after the creation of the Czech Securities Exchange Commission in January 1998. Led by economists such as Tomas Jezek, who later became the head of the SEC and who according to one former fund manager "had no knowledge of capital markets," (see Personal Interview, Prague, April 24, 2005) the Czechs thought that giving the role of oversight to a new regulator would eliminate many of the existing agency problems. Unfortunately the problems that people associated with ineffective enforcement by the courts and the Ministry of Finance did not go away after the creation of the SEC. One of the criticisms of the Ministry of Finance was that many of their employees were unknowledgeable about securities markets, but when they created the new SEC they ended up hiring many of those same who were just as unknowledgeable as when they worked for the Ministry of Finance (see Calbreath, 1996). Saying that regulators will prevent fraud is one thing, but implementing it through the political process in practice is another.

Regulators are often just as in the dark about a company's future behaviour as the typical investor, and unless regulators can easily identify wrongdoers, they will often attempt to devise proxies that are quite arbitrary. For example, because a certain percentage of funds were not acting in the fiduciary interests of their investors, the Czech government decided to restrict the number of investment funds. Tomas Jezek told us in our interview that he was incredulous about the number of brokers and investment funds in the early days and he argued that that one of the most important tasks of the SEC was to reduce this number to a more realistic figure (see Personal Interview, Prague, July 22, 2002). Through various schemes they raised the fixed costs of regulations which ended up putting many small firms out of business but why reducing the number of companies will reduce the amount of fraud is unclear. Technically it is correct that if they put many firms out of business, they would put some fraudulent firms out of business, but in the process they ended up severely restricting the amount of competition. Stigler's (1964) capture theory of regulation is alive and well.

In addition to making firms jump through many regulatory hoops, the government created restrictions on who could work at brokerage firms which further re-

10) From a political economy perspective, the analysis of regulation is incomplete unless it accounts for the problems of knowledge (see Hayek, 1948; Sowell, 1980; Kirzner, 1985), and the problem of interests (see Stigler, 1975; Buchanan, Tollison, Tullock, 1980). While distinguishing between the problems is important, these problems are often intertwined (see Boettke, 1993, 2001). James Buchanan (1969, p. 96-97) argues that the knowledge problem is important, but he believes that the incentive problem is more important: „Even if the socialist state should somehow discover an oracle that would allow all calculations to be made perfectly, even if all preference functions are revealed, and even if all production functions are known with certainty, efficiency in allocation will emerge only if the effective decision-makers are converted into economic eunuchs. Only if such men can be motivated to behave, to make decisions in accordance with cost criteria that are different from their own can this decision-structure become workable. This amounts to saying that even if the problems of calculation are totally disregarded, the socialist system will generate efficiency in results only if men can be trained to make choices that do not embody the opportunity costs that they, individually and personally, confront." Lavoie (1985, p. 102) reverses the argument saying that even if the planners could be converted into a eunuch, the problems of calculation could not be overcome. We contend that modern political economy must challenge the assumptions about both benevolence and omniscience.

11) Paliwoda (1995, p. 76) writes, "Outwardly, the [Czech] government projects an image that is aggressively pro-market economy, but internally the administration is lacking and appears to have little enthusiasm for these stated policies. Promises are frequently made, but few have the power to fulfill them." 
duced the amount of competition. To Petr Ladzov of the SEC, it was unacceptable that boards of investment funds, „had people with only basic or elementary school education who were making decisions about the assets of their shareholders" (quoted in Friedrich, 1998, p. A12). According to another SEC member, with the new regulations many unsanctioned "managers don't have enough official experience or education to qualify" (quoted in Friedrich, 1998, p. A12). ${ }^{12)}$ Other regulations restricted where Czechs could invest and how funds could be offered; any foreign fund sold was required to have over half of its resources in OECD countries and to meet a number of registration and operating requirements, all of which reduced choices for investors (see Vykoukal, 2001, p. 22).

The list of bad regulations is long, but perhaps the most astonishing regulation: to deal with the problem of low liquidity, the government passed measures that ensured that these stocks were traded even less. In developed markets such as the US, public companies that do not meet New York Stock Exchange listing requirements can be traded over-the-counter and listed in the Pink Sheets, and just as many market makers and brokers are willing to trade these stocks in the US, a similar market had emerged in Prague. Low liquidity stocks in the Czech Republic were typically traded through the RM-System ${ }^{13)}$ rather than on the Prague Stock Exchange, but Czech officials reasoned that because trading in these stocks was less than regulators would have liked, it was better to prevent people from trading these stocks at all. Equities that formerly had value became worthless when the Czech officials eliminated their markets (see Bouc, 2001) and in the two year period after the creation of the SEC, the trading volume on the RM-System went down by 90 percent (see Stringham, Boettke, 2005). If the Czech regulators' goal was to decrease interest in the stock market they must be rated as doing an excellent job, ${ }^{14)}$ but they have not eliminated fraud and they have not made the Prague Stock Exchange the place to invest. ${ }^{15)}$

\section{Conclusion}

Law-centered approaches have unrealistic expectations about problems the government can solve and they have led to many misguided policy conclusions. Mises (1998) and Hayek (1948) rightly criticized the market socialists for thin-

12) One might argue that if regulators need to be educated about financial markets so do managers but we would disagree. The profit and loss mechanism automatically selects the appropriate education level of market participants but with regulators the incentives are completely different. If a manager is not educated enough to satisfy the demands of his customers he will end up losing money, but if a regulator is not educated enough to understand the market he is regulating then his subjects will end up losing money.

13) Some say that the RM-System was only able to develop because the Czech Republic did not start with such restrictive regulations. In 1995, one director of the RM-System said: „If we had called for tougher regulations two years ago, we would never have gotten a license to develop our businesses. I hope we will remember this." (quoted in Lawson, 1995, p. 5)

14) One former fund manager said that was their intent: „They worked a lot to put the RM-System out of business because it did not fit with the regulatory vision of the SEC. It was too unregulated" (see Personal interview, Prague, April 24, 2005).

15) Lesenarova (2001, p. 5) gives this report of the Prague Stock Exchange nearly three years after the creation of the SEC: "Only 11 of the PSE's 43 members remain on the SPAD, a trading system using market makers, which offers more share liquidity. In spring 2000 there were 18 . The number of PSE members has also seen better days; it used to have 55 members last year. A small market and low volumes which generate increasingly fewer fees for brokerages have taken their toll among the minnow players, and their ranks have dropped as well from 440 in 1998 to 108 currently. However, 40 out of the 108 are under administrative proceedings of the Securities and Exchange Commission (KCP) for violating disclosure duty and other problems." 
king that government managers could be told to "play market," and many of the same criticisms apply here: managers need to be motivated by market incentives rather than bureaucratic rules that mandate profit maximization. One of the main problems with Czech privatization was the process contained a large degree of government influence. Rather than selling off the assets of government run enterprises and giving ownership to someone who could hire their own managers, the Czech scheme often kept government managers in place and then and then told them to work for the benefit of their newfound shareholders. Despite what the new laws said, these managers, who had been appointed under communism, did not necessarily have the profits of "their investors" as their number one priority. ${ }^{16)}$ Yet the legal centralist approach unrealistically believed that this principal agent problems could by solved by simply passing more laws.

A more sensible approach would have focused on harnessing market incentives rather than passing additional laws. Western market institutions have been evolving for centuries, so rather than trying to recreate every financial institution de novo the Czechs might have been well advised to sell more assets in complete chunks and rely on private institutions from other countries. For example, one way to privatize was the method Czechs used with most firms: create shares with dispersed ownership and then hope everything works out. Another method is to simply sell the firms in large chunks and get government management out of the way as soon as possible. ${ }^{17)}$ This is what the Czechs did when they sold the auto manufacture Skoda to Volkswagen in 1991 and many consider this to be a success. ${ }^{18)}$ Given that Volkswagen and many other Western companies do not have proble$\mathrm{ms}$ of bad corporate governance, by quickly selling the firms to them it enables to Czechs to get around the problem of creating good corporate governance from scratch. The Czechs could have done this not just for a car company but for investment companies, stock exchanges, and banks. Schwarz (1999, p. 3) writes „Full privatization will bring, along with the long awaited foreign capital and investments - the sources of our economic growth - a positive secondary effect for the dying capital market, which is now fighting the childish illness of the Czech Security Exchange Commission." By enabling established companies to enter the picture and appoint their own managements, the assumed need for carefully crafted and enforced Czech laws goes away.

The Czech government has relied heavily on the legalistic approach to deal with problems, and empirically it has not delivered. It must be recognized that government courts and regulators are imperfect agents who have a difficult time weighing their benefits and costs of their actions and they lack disciplinary mechanisms found in the marketplace. Ultimately regulators, just like courts, are another branch of government, and if the problems that plague judicial enforcement in the

16) Schwarz (1998, p. 1) argues that when government remains so involved, people often mistakenly attribute the government problems to markets. He writes „Partial privatization (still existing joint stock companies with a large amount of state shares, or under tough regulations, which is almost the same thing) discredited the process of transformation."

17) This is just one possible way of privatizing, but one that involves less of the potential principal agent problems stemming from dispersed ownership of quasi state managed firms.

18) Skoda was actually sold in phases with the government retaining a thirty percent ownership stake for a few years, but „More importantly.... [the government] guaranteed Volkswagen that it would not interfere in the management of the company" (see Sullivan et al. 2004, p. 19). If firms have the ability to replace existing management the firms will be worth more and can sell for more than if government stays heavily involved as it often did. Schwarz (2001) writes „Typical industrial policies during a transition period are non-systematic, half-way, unfinished and mutually incompatible. Every delay in privatization processes decreases the price of state owned assets." 
Czech Republic are also present with the regulatory authority, then shifting the burden of monitoring and enforcement from judges to regulators is not an efficient solution. By thinking the problem of corporate governance is essentially a legal problem, the Czechs have been focusing resources in all of the wrong places. Next time they should think about relying on the benefits of markets rather than trying to rely on regulation.

References

Banner, S. (1998), Anglo-American Securities Regulation: Cultural and Political Roots 1680 1860. Cambridge: Cambridge University Press.

Benson, B. (1990), The Enterprise of Law. San Francisco: Pacific Research Institute for Public Policy.

Benston, G. (1998), Regulating Financial Markets: A Critique of Some Proposals. London: Institute of Economic Affairs.

Bernstein, L. (1992), "Opting out of the Legal System: Extralegal Contractual Relations in the Diamond Industry," Journal of Legal Studies, 21, pp. 115-157.

Black, B. (2001), "The Legal and Institutional Preconditions for Strong Securities Markets." UCLA Law Review, 48, pp. 781-855.

Boettke, P. (1993), Why Perestroika Failed. New York: Routledge.

Boettke, P. (2001), Calculation and Coordination. New York: Routledge.

Bouc, F. (2001), "Cesky Telecom Chosen Most Open." The Prague Post, April 11, 2001: Business 1 par. in Lexis/Nexis [database online].

Bouc, F. (2004), "Speeding up justice: Law firm promotes arbitration for small and midsize businesses." The Prague Post, May 22.

Brennan G., Buchanan, J. (1985), The Reason of Rules. Cambridge: Cambridge University Press.

Buchanan, J. (1969), Cost and Choice: An Inquiry in Economic Theory. Chicago: University of Chicago Press.

Buchanan, J. (1975), The Limits of Liberty. Chicago: University of Chicago.

Buchanan, J., Tollison, R., Tullock, G. (1980), Toward a Rent Seeking Society. College Station: Texas A\&M Press.

Calbreath, D. (1996), "In Winter's Gloom, A Ray Of Optimism." The Prague Post, December 18, A9.

Chemmanur, T., Fulghieri, P. (2001), "Choosing an Exchange to List Equity: A Theory of Cross-Listing, Listing Requirements, and Competition Among Exchanges." Massachusetts, Boston College, Working paper.

Clay, K. (1997), "Trade Without Law: Private-Order Institutions in Mexican California," Journal of Law, Economics, and Organization, 13, pp. 202-231.

Coase, R. (1994), "Economists and Public Policy," in Essays on Economics and Economists. Chicago, University of Chicago Press, pp. 47-63.

Coffee, J. (1999), "Privatization and Corporate Governance: The Lessons from Securities Market Failure." Journal of Corporation Law, 25, pp. 1-39.

Diamond, D. (1989), "Reputation Acquisition in Debt Markets." Journal of Political Economy, 97, pp. 828-862.

Easterbrook, F. (1997), "International Corporate Differences: Markets or Law?" Journal of Applied Corporate Finance, 9 (4), pp. 23-29.

Ellickson, R. (1987), "A Critique of Economic and Sociological Theories of Social Control." Journal of Legal Studies, 16(1), pp. 67-99.

Ellickson, R. (1991), Order without Law: How Neighbors Settle Disputes. Boston: Harvard University Press.

Friedrich, A. (1998), "Inspections Loom on Capital Market." The Prague Post October 27, 1998, A5, A12.

Frye, T. (2000), Brokers and Bureaucrats: Building Market Institutions in Russia. Ann Arbor: University of Michigan Press. 
Glaeser, E., Johnson, S., Shleifer, A. (2001), "Coase versus the Coasians," Quarterly Journal of Economics, 116, pp. 853-899.

Greenfield, K., Kostant, P. (2003), “An Experimental Test of Fairness Under Agency and Profit-Maximization Constraints (With Notes on Implications for Corporate Governance)" George Washington Law Review, 71, pp. 983-1024.

Hart, O., John M. (1988), "Incomplete Contracts and Renegotiation." Econometrica, 56, pp. 755-785.

Hayek, F. A. (1948), Individualism and Economic Order. Chicago: The University of Chicago Press.

Johnsen, D. B. (1986), "The Formation and Protection of Property Rights Among the Southern Kwakiutl Indians." Journal of Legal Studies, 15, pp. 41-67.

Johnson, S., La Porta, R., Lopez-de-Silanes, F., Shleifer, A. (2000), "Tunneling." American Economic Review, 90, pp. 22-27.

Kirzner, I. (1985), Discovery and the Capitalist Process. Chicago: University of Chicago Press.

Klein, P. G. (1996), "Economic Calculation and the Limits of Organization." Review of Austrian Economics, 9, pp. 3-28.

Lavoie, D. (1985), Rivalry and Central Planning. New York: Cambridge University Press.

Lawson, M. L. (1995), "A Call For Disclosure In Securities Market." The Prague Post May 17, 1995.

Leeson, P. "Cooperation and Conflict: Evidence on Self-Enforcing Arrangements and Hetergeneous Groups." American Journal of Economics and Sociology, forthcoming.

Lesenarova, H. (2001), "News Exchange Gets To Grips With Its Falling Stock PSE Hits Two-Year Low While Players Reduce, Cease Trading Activity." Prague Business Journal, July 16, 2001, 31 pars. in Lexis/Nexis [database online].

Mahoney, P. (1997), "The Exchange as Regulator." Virginia Law Review, 83, pp. 1453-1500.

Manne, H. (ed.) (1969), Economic Policy and the Regulation of Corporate Securities. Washington: American Enterprise Institute.

McLindon, M. (1996), Privatization and Capital Market Development: Strategies to Promote Economic Growth. Westport, CT: Praeger.

Mises, L. V. (1990), Economic Calculation in the Socialist Commonwealth. Auburn, AL: Mises Institute.

Mises, L. V. (1998), Human Action. Auburn, AL: Mises Institute.

MIčoch, L. (2000), "Restructuring of Property Rights: An Institutional View," in Mlčoch, L., et al., ed., Economic and Social Changes in Czech Society After 1989. Prague: The Karolinum Press.

Olson, M. (1996), "Big Bills Left on the Sidewalk: Why Some Nations are Rich, and Others poor." Journal of Economic Perspectives, 10, pp. 3-24.

Padilla, A. (2002), "Can Agency Theory Justify the Regulation of Insider Trading?" Quarterly Journal of Austrian Economics, 5 (1), pp. 3-38.

Paliwoda, S. (1995), Investing in Eastern Europe: Capitalizing on Emerging Markets. Workingham, England: Economist Intelligence Unit.

Palmer, T. (1997), "Preface to Renaissance," introduction to Václav Klaus Renaissance: The Rebirth of Liberty in the Heart of Europe. Washington, D. C.: Cato Institute.

Pistor, K. (2001), "Law as a Determinant for Equity Market Development - The Experience of Transition Economies," in Murrell, P., ed., The Value of Law in Transition Economies. Ann Arbor: Michigan University Press, pp. 249-287.

Santomero, A. (1998), "Design of Financial Systems and Economic Transformation," Financial Sector Reform and Privatization in Transition Economies, in Doukas, J., Murinde, V., Wihlborg, C., eds., Elsevier Science: Amsterdam, pp. 153-174.

Sappington, D. (1991), "Incentives in Principal-Agent Relationships." Journal of Economic Perspectives, 5, pp. 45-66.

Shleifer, A., Vishny, R. (1997), "A Survey of Corporate Governance." Journal of Finance, 52, pp. 737-783.

Schwarz, J. (1998), "Still Halfway." Manuscript, Prague, Liberální Institut. 
Schwarz, J. (1999), "The Forgotten Economics Transformation: Transformation at a Deadlock." Hospodářské noviny.

Schwarz, J. (2001), "Deregulation vs. Re-Regulation.” Journal des Economistes et des Etudes Humaines, 11 (4), pp. 669-684.

Šíma, J., Š•astný, D. (2000), "A Laissez-Faire Fable of The Czech Republic." Journal of Libertarian Studies, 14, pp. 155-178.

Sowell, T. (1980), Knowledge and Decisions. New York: Basic Books.

Sullivan, J., Rogers, J., Shkolnikov, A. (2004), "Privatizing State-Owned Companies." Center for International Private Enterprise Economic Reform Issue Paper Number 403.

Stigler, G. (1964), "Public Regulation of the Securities Market." Journal of Business, 38, pp. 117-142.

Stigler, G. (1975), The Citizen and the State: Essays on Regulation. Chicago: University of Chicago Press.

Stiglitz, J. (1999), "Whither Reform. Ten Years of the Transition." Washington, Keynote Address, Annual Bank Conference on Development Economics, April, pp. 28-30.

Stringham, E. (2001), "Kaldor-Hicks Efficiency and the Problem of Central Planning." Quarterly Journal of Austrian Economics, 4, pp. 41-50.

Stringham, E. (2003), "The Extralegal Development of Securities Trading in Seventeenth Century Amsterdam." Quarterly Review of Economics and Finance, 43 (2), pp. 321-344.

Stringham, E., Boettke, P. (2005), "Are Regulations the Answer for Stock Markets in Transition? An Assessment of the Public Interest Theory of Regulation in the Czech Experience." Fairfax, George Mason University, Department of Economics, Working paper.

Vykoukal, P. (2001), "Focus: Modern Options to Money Management." Prague Tribune, May 28, 22 pars. in Lexis/Nexis [database online].

Wallace, C. (1996), "The Pirates of Prague." Fortune, December 23.

Williamson, Oliver, E. (1983), "Credible Commitments: Using Hostages to Support Exchange" American Economic Review, 73 (4), pp. 519-540.

Zemplinerova, A. (2000), "The Czech Republic," in Atrisien-Maksimenko, P., ed., Multinationals in Eastern Europe. Hampshire, Macmillan Press, pp.125-150. 


\title{
THE FAILINGS OF LEGAL CENTRALISM FOR HELPING STOCK MARKETS IN TRANSITION
}

Edward STRINGHAM, Department of Economics, San Jose State University, San Jose, CA 95192 (e-mail: edward.stringham@gmail.com); Peter BOETTKE, Department of Economics, George Mason University, Fairfax, VA 22030 (e-mail: pboettke@gmu.edu)

\begin{abstract}
:
After Czech voucher privatization many companies simply ignored the interests of their shareholders. The government has since increased the amount of regulation, but they have failed to establish significant investor confidence. This article offers some explanations of why their legal centric approach remains unlikely to create good corporate governance. Mandating that companies maximize shareholder value is easier said than done because it requires government to assess whether companies are making optimal business decisions. In former communist countries especially, government officials are ill suited to make such judgments because they lack the knowledge of how businesses should be properly run. Increased bureaucratic oversight in the Czech Republic has simply burdened markets without any noticeable positive results. This article discusses how good corporate governance can only be a byproduct of markets where managers compete for investors rather than something that can be created by law.
\end{abstract}

Keywords: Czech stock market transition, regulation, corporate governance, legal centralism

JEL Classification: G1, K2, P2 